\title{
Application of Oat as a Test Plant for Studying Ecological Longevity
}

\author{
Kolomiytsev A. K. \\ MD, PhD, Rostov State Medical University
}

\begin{abstract}
The paper proposes the possibility of using oat as a test plant for studying ecological longevity. A model suggested here enables to study the longevity of a plant population in conditions of limited nutritional resources while maintaining all the other ambient parameters. Furthermore, it is possible to conduct the research on the changes in the influence of various parameters on the longevity of the population within the limited periods of time.
\end{abstract}

Keywords—aging, plant aging, ecological longevity.

\section{INTRODUCTION}

The study of the processes of plant aging has a great theoretical value for forming the understanding of this process as a systemic natural phenomenon, inherent in the multicellular organisms of both, plant and animal origin, as well as an important practical value in the context of getting the data about physiological and ecological plant longevity and their stress resistance when exposed to various physical factors. The reasons for plant aging are understudied. It is generally assumed that aging takes place in all the species both in the cultivated crops and in the wild plants [1]. Most findings on plant aging and longevity are indirect; they are based on registering the date of planting various species and their death, as well as on counting the number of rings on tree cuts. Plant longevity is conventionally accessed as a labile value dependent on the external conditions [2].

According to a number of authors there are some potentially immortal plant organisms, which keep growing until they are destroyed by some external lethal factor [3]. This is why studying the processes of plant aging is of great interest. Particularly, the plants that grow the infinite number of vegetative shoots, represent a model similar in systemic properties to the communities of unicellular organisms, which is why it is difficult to define lifespan of each separate organism. In the latter case, the definition of aging becomes philosophic, rather than strictly scientific.

Plant longevity is usually divided into ecological and physiological. While physiological longevity is defined as the life limit of the representatives of a given species in the most favorable conditions, ecological longevity is its mean value in the natural habitat. The limits of its variability are specific for different individual plants; it depends on changeability of many physical factors of the habitat [4].

The process of aging in plants has its specific features. Particularly, new cells, tissues and organs are established and continue to grow during the whole plant ontogenesis. This is why a grown plant at each given period of time has both young and dying organs [5]. On the organism level growth generally continues up till senility with a particular tendency towards slowing down.

Theories of plant aging can be divided into 3 main groups.

The first group of theories implies that aging and death are a genetically programmed process. This mechanism is most prominent in annual plants. Verity of the aging program can be proved by the existence of the limited amount of cellular divisions (the Hayflick limit) [6]. The second group of theories regards aging as gradual accumulation of random mistakes in gene expression.

The third group of hypotheses is evolutionary: aging is a period of life left out by the natural selection. Natural selection is aimed at ensuring the reproductive function of the species, which is why its influence decreases after the function is implemented [7]. In order to confirm these hypotheses one should compare the efficiency of plants' fruitification and the speed of their consequent death. The more successful the fruitification, the higher the following degeneration must be [8].

All in all, it is possible to suggest that plant aging is a systemic process [9]. The main theories of plant and animal aging are similar in the methods of their realization [10].

Aim of the research: to study the possibility of using oat as a model for studying ecological longevity and its variability depending on the ambient factors.

\section{MATERIALS AND METHODS}

It is proposed to use oat sprouts grown on a thin layer of ground to study longevity in conditions of limited nutritional resources. In order to implement the proposed method we used thin plastic containers with a thin layer of ground (no more than $0,5 \mathrm{~cm}$ in thickness), upon which we placed oat seeds in one layer; the ground was kept wet during the experiment. Limiting the culture in nutritional resources allows us to control the ecological longevity 
within created conditions, which at that allows us to study its changes under the influence of various ambient factors and their parameters within rather limited time periods. It may be useful for acceleration in conducting large series of experiments.

To set an example, we have studied the influence of a constant magnetic field on the ecological longevity of oat culture. Planting the seeds was conducted in the same way as described above. During the experiment a source of the constant magnetic field - a magnet with induction of 50 $\mathrm{mT}$ - was placed close to the container. Simultaneously, we have conducted a control experiment, in the case of which the influence of the external sources of the magnetic field was excluded. All the other conditions, such as lighting, watering, air temperature, stayed the same.

\section{RESULTS}

A total of 10 experiments were carried out. In the first series, the test group was influenced by a constant magnetic field for the period of 10 days since the seeds began to grow. In the control group the influence of the steady magnetic field was excluded. Assessment of the ecological longevity of the culture was performed: 1 . considering the time since the beginning of the experiment till the first signs of plant death appeared; 2 . considering the time of complete plant death.

The following data were obtained:

During the experiment, the first signs of degradation in the form of yellowing are marked in 20-25 days since the beginning of the experiment, in the control group such changes are discovered in 18-20 days, In the control group, complete plant death occurs in 30-35 days, in the test group, there is a degradation of $7-80 \%$ of plants during this period, complete death of the culture generally occurs after 40-45 days since the beginning of the experiment. Thus, in the test group under the influence of a magnetic field complete death of the culture generally occurs $23,3 \%$ later than in the control group.

\section{CONCLUSIONS}

The possibility of using oat as a model plant for studying ecological longevity and its changeability depending on the ambient factors has been studied. The proposed model allows to study the factors that affect ecological longevity in conditions of limited nutrition resources and significantly decrease the time of conducting the experiments. Particularly, it has been shown that when the oat population is under the influence of an artificial steady magnetic field, its ecological longevity is generally increased by $23,3 \%$.

\section{REFERENCES}

[1] Gupalo P.I. Vozrastnye izmenenija rastenij i ih znachenie $\mathrm{v}$ rastenievodstve [Age-related changes in plants and their significance in crop research]. M.: 1969.- P. 252 [in Russian]

[2] Salamatova T.S. Fiziologija rastitel'noj kletki [Physiology of a plant cell]. L.: 1983.- P. 232 [in Russian]

[3] Polevoj V.V., Salamatova T.S. Fiziologija rosta i razvitija rastenij [Physiology of plant growth and development]. L.: 1991.- P. 240 [in Russian]

[4] Aliev M.G. Ekologicheskie predposylki starenija i prodolzhitel'nosti zhizni list'ev [Ecological prerequisites for aging and longevity of leaves]. Mahachkala: 2010.- P. 109 [in Russian]

[5] Krenke N.P. Regeneratsija rastenij [Plant regeneration]. M.:1950.- P. 675 [in Russian]

[6] Hayflick L. Biological aging is no longer an unsolved problem. Ann N Y Acad.Sci.2007Apr;1100:1-13.

[7] Gavrilov, L., Gavrilova, N. Evolutionary theories of aging and longevity. TheScientificWorldJOURNAL (2002) 2, 339-356.

[8] 8.. Zhmylev P. U. Evoljutsija dlitel'nosti zhizni rastenij: fakty i gipotezy. Zhurnal obshhej biologii [Evolution of plant longevity: facts and hypotheses// Journal of General Biology]. V. 67, 2006. № 2, March-April. P. 107-119 [in Russian]

[9] Kolomiytsev A. K. Sistemnaja strukturnaja gipoteza starenija: protsess starenija u rastitel'nyh organizmov. Mezhdunarodnyj nauchnoissledovatel'skij zhurnal [Systemic structural hypothesis of aging: the process of aging in plants// International Scientific Research Journal]. 2015. № 9-3 (40). P. 16-18 [in Russian]

[10] Kolomiytsev A. K. Starenie organizma kak svojstvo strukturnoj organizatsii biosistem [Aging of an organism as a property of biosystemic structural organization]. M.: Editus, 2012.- P. 138 [in Russian] 